DOI https://doi.org/10.18551/rjoas.2020-11.10

\title{
CORAL REEF CONDITION WITH CHAETODONTIDAE FISH AS THE INDICATORS IN THE WATERS OF THE SAMBER GELAP ISLAND OF KOTABARU, SOUTH KALIMANTAN
}

\author{
Iskandar Rina* \\ Doctoral Program of Agriculture Science Department, University of Brawijaya, East Java \& \\ Department of Fisheries, Faculty of Agriculture, University of Achmad Yani Banjarmasin, \\ South Kalimantan, Indonesia \\ Soemarno, Kusuma Zaenal \\ Department of Agroecotechnology, Faculty of Agriculture, University of Brawijaya, Malang, \\ East Java, Indonesia \\ Wiadnya Dewa Gede Raka \\ Department of Fisheries and Department of Marine Resources Utilization, \\ Faculty of Fisheries and Marine Science, University of Brawijaya, Malang, Indonesia \\ *E-mail: oriens rin@yahoo.com
}

\begin{abstract}
Coral reefs are ecosystems with a very high diversity of species that function as dwellings and grow for other biota. Coral reef is a community of organisms that live on the bottom of the water and in the form of limestone $\left(\mathrm{CaCO}_{3}\right)$ which is strong enough to withstand the waves of the sea. Coral reefs are built from massive deposits of calcium carbonate produced by reef-forming coral organisms (hermatipic corals) from the Coridaria phylum, the order of Scleractinia which is symbiotic with zooxantellae and a few additional calcareous algae and other organisms that extract calcium carbonate. Fish indicator is an indicator for the level of fish fertility in coral reefs. Chaetodontidae or Kepe-kepe fish are true reef fishes and their distribution is only around coral reefs. The experts agreed in placing kepe-kepe fish as an indicator species of coral reef condition, because these fish are true reef dwellers. This study aimed to determine the relationship between the condition of coral reefs and the abundance of Chaetodontidae fish in the waters of Samber Gelap Island, Kotabaru Regency, South Kalimantan. This research was conducted in April 2019. The research method used was the field observation methods with the sampling method using the line transect method on coral data and fish transect on fish data along $30 \mathrm{~m}$. Data taken in this study were physical parameter data, coral cover data, and fish abundance. The results of this study indicated that the quality of waters in Samber Gelap Island Waters supported the life of coral ecosystems. The highest percentage of coral cover was at station 5 with a percentage of $42.08 \%$ and included in the medium category. This result was directly proportional to the abundance of indicator fish at station 5 which had the highest number of 13 individuals ( 3 species) of the Chaetodontidae family. Correlation test results between the conditions of coral reef cover on the abundance of indicator fish produced a correlation value of 0.8 with a very strong category. These results meant that the condition of coral cover had a strong influence on the abundance of indicator fish, but it was not the only factor affecting the abundance of indicator fish in the waters of Samber Gelap Island, Kotabaru, South Kalimantan.
\end{abstract}

\section{KEY WORDS}

Fish indicator, coral reef coverage, Chaetodontodae, Samber Gelap, South Kalimantan.

Coral reefs have an important role in maintaining the sustainability of ecosystems in the sea (Edrus et al., 2013). Dahl (1981) said that the substrate of the sea floor such as sand, mud, coral fractures or rock substrate types is the percentage of the main area when 
compared with the percentage of coral coverage. Coral reef coverage category consists of hard coral, soft coral and dead coral.

Indicator fish is one type of fish that inhabits coral reef habitats. Coral reefs can also support fish diversity. The diversity of morphology and color of fish bodies is a result of adaptation to the environment. The Chaetodontidae family is an indicator fish species for coral reefs, because the fish of the Chaetodontidae family are the species most strongly associated with corals or highly dependent on the presence of coral reefs in a waters (Suharyanto and Utojo, 2007). According to Rondonuwu and Rembet (2013) fish from the family chaetodontidae or which have local names butterfly fish are one of the coral fish families which are indicators of the healthy condition of coral reefs.

Indicator fish is a fish from the family chaetodontidae, also widely known as kepe-kepe fish. This type of kepe-kepe fish can be identified by the characteristics of the various color patterns. In healthy coral waters many species of indicator fish are found. Indicator fish has a function as a sign that healthy or not coral reefs in the waters. The small number of indicator fish indicates that the coral reefs in these waters are disturbed (Edrus et al. 2013).

Chaetodontidae or Kepe-kepe fish are true reef fishes and their distribution is only around coral reefs (Burges, 1978). Burges believes that Kepe-kepe fish will be found on every coral reef. He confirmed this assumption because as far as he was aware that Kepekepe fish must have been found in the coral reef community in good condition.

Coral reefs in the waters of South Kalimantan (especially the type of coastal coral reefs) are found in the inland waters of Kalimantan and around P. Sea. Common types of coral reef structures are fringing reefs, such as those found in Kotabaru District, and takat corals ( patch reefs or platform reefs) which are commonly found in Tanah Bumbu Regency. Conditions vary, ranging from death to very good. However, most are in a heavily damaged condition (Asmawi, 2010).

The Samber Gelap Islands consist of four small islands namely Maraeng Island, Halang Malingkau Island, Samber Dark Island, and Sawah Island. Although it is located far from Pulau Laut (the capital of the regency), the Samber Gelap Islands is now one of the marine tourism destinations that is increasingly being looked at by marine tourism lovers. Because it has its own uniqueness, such as white sand along the beach, turtle breeding sites, and there are also coral reefs. But there has been no research / there is still little research on coral reefs and coral fish in the Samber Dark Islands. Therefore, more complete information is needed that is not only related to the condition of coral reefs and reef fish, but also important to analyze the relationship between the two. Based on this, it is important to conduct this research with the aim to determine the relationship between the condition of coral reefs and the abundance of Chaetodontidae fish in the waters of Samber Dark Island, Kotabaru Regency, South Kalimantan.

\section{MATERIALS AND METHODS of RESEARCH}

The material of this research included the taking of data on the percentage of coral cover and abundance of Chaetodontidae fish at the study site

The study was conducted in April 2019 in the waters of the Sambar Dark Islands, Kotabaru Regency, South Kalimantan. The sampling location (station) was determined intentionally (purposive sampling). The sampling point determination technique was based on the consideration that the chosen location could represent the waters of the Samber Gelap region as a whole, marked by the help of GPS (Global Position System).

The procedures carried out in this study consisted of determining the station point, data collection for water quality, observing the types and conditions of abundance of indicator fish, observing the condition of coral cover, processing data on results of coral cover photos or videos, and processing of photos or video data of indicators.

The oceanographic hydro parameters measured were clarity, temperature, direction and speed of current, and salinity at each observation station. Measurement of each water parameter using the tools listed in Table 1. 


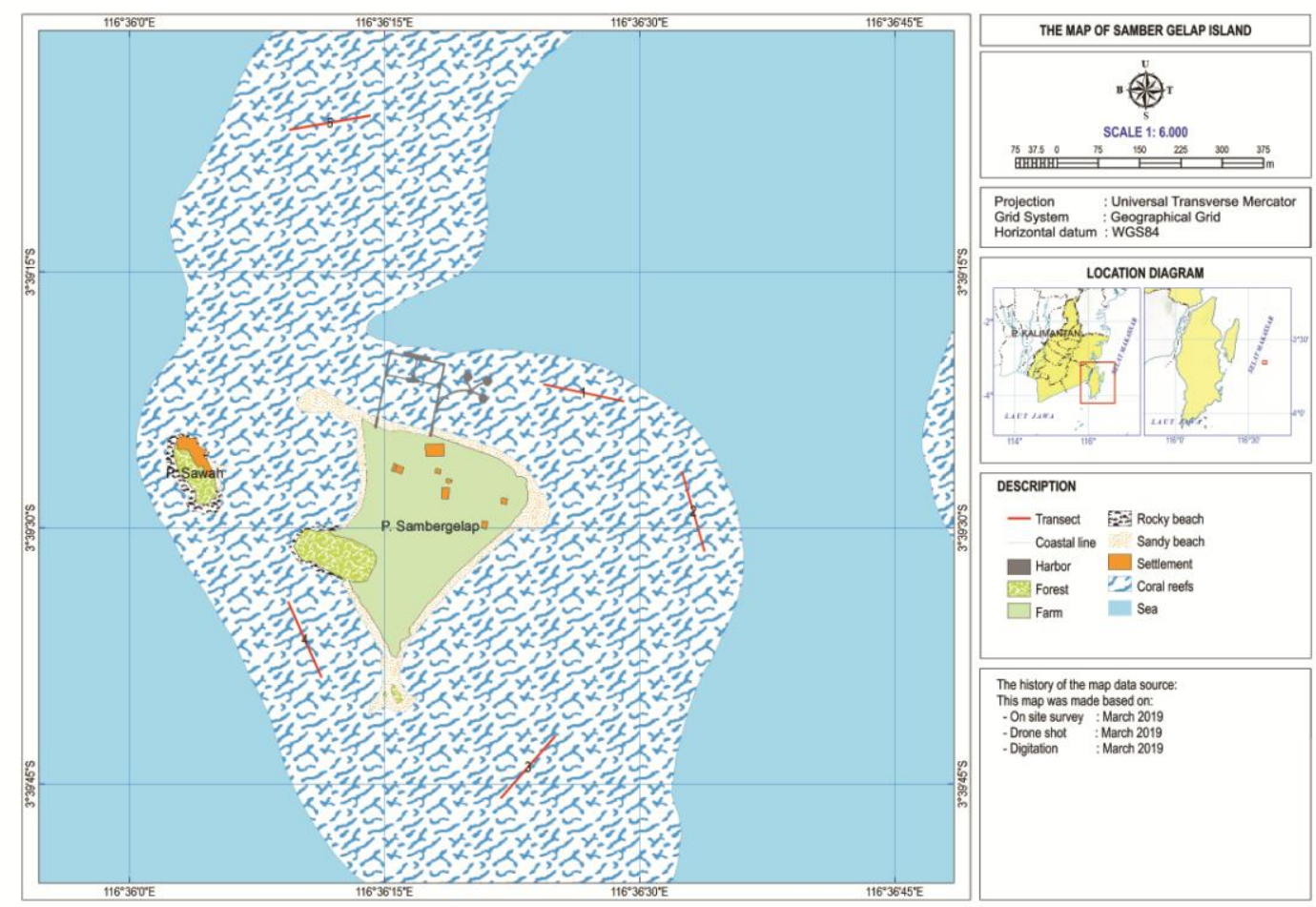

Figure 1 - Research Site

Table 1 - Hydro oceanographic parameters and equipment used in the study

\begin{tabular}{llll}
\hline No. & Parameter & Unit & Tool \\
\hline 1 & Temperature & ${ }^{\circ} \mathrm{C}$ & Termometer \\
2 & Salinity & $\% \circ$ & Refraktometer \\
3 & Clarity & $\%$ & Secchi disk \\
4 & Current speed & meter/detik & Floating drouge \\
5 & Depth & Meter & Secchi disk \\
\hline
\end{tabular}

Coral data retrieval was done by the line transect method used to determine the percentage of coral cover that refered to the line intercept transect method (English et al. 1994). Coral identification refered to (Veron, 2000) and was strengthened by Suharsono (2008). Installation of line transects was done by placing garments transects 50 meters long.

This study used the Underwater Visual Census (UVC) method or transects using video for recording refered to (English et al. 1994). The identification of reef fish indicators refered to Allen and Steene (1996) and was strengthened by Setiawan (2010). Transect installation was done by pulling a roll meter along 50 meters. The width of the belt transect used an area of $100 \mathrm{~m} 2$ with coverage of $1 \mathrm{~m}$ to the right and $1 \mathrm{~m}$ to the left of the LIT length of $50 \mathrm{~m}$. Data capture of indicator fish was done by recording using an underwater camera. Recording was done after waiting for calm waters for about 15-20 minutes, so the fish return to fill the coral reef. Analysis of the data used in this study consisted of analysis to calculate the abundance of indicator fish, determine the percentage of coral cover, determine the diversity index $\left(\mathrm{H}^{\prime}\right)$, uniformity index (E), dominance index (D) and calculate the correlation between the percentage of coral cover with fish abundance indicator. al, 1997):

The percentage of coral reef cover was calculated with the following formula (English et

$$
\mathrm{C}=\frac{\alpha}{A} \times 100 \%
$$

Where: $\mathrm{C}=$ Lifeform overage percentage $I(\%) ; \alpha=$ Lifeform transect length ; $\mathrm{A}=$ Transect total length (meter). 
According to Kep. MENLH No 4 tahun 2001; Gomez and Yap (1988), there are four criteria of coral reef as follows:

Table 2 - Criteria of coral reef cover percentage

\begin{tabular}{ll}
\hline$\%$ cover & Category \\
\hline $75-100$ & Excellent \\
$50-74,9$ & Good \\
$25-49,9$ & Fair \\
$0-24,9$ & Poor \\
\hline
\end{tabular}

Fish abundance indicators are calculated using the Odum formula (1996):

$$
X=\frac{x i}{n}
$$

Where: $X=$ Coral reef fish abundance $\left(\mathrm{ind} / \mathrm{m}^{3}\right) ; \mathrm{xi}=$ Number of fish in the-i observation Transect; $\mathrm{n}=$ Transect area $\left(\mathrm{m}^{2}\right)$.

The correlation of the percentage of coral reefcover and the abundance of coral reef fish was calculated using the Multiple Linear Regression method with $R$ software applications. Thepurpose of Multiple Linear Regression analysis was tomeasure the intensity of the correlation between two ormore variables and predict the estimated $\mathrm{Y}$ value over $\mathrm{x}$. According to Nachtsheim et al. (2004), the common form of Multiple Linear Regression was obtained following formula:

$$
Y=a+b_{1} x_{1}+b_{2} x_{2}
$$

Where: $Y=$ Dependent variable; $A=$ Constant; $b_{1}, b_{2}=$ Regression coefficient; $\mathrm{x}_{1}, \mathrm{x}_{2}=$ Independent variable.

\section{RESULTS of STUDY}

The results of measurements of water quality which was a limiting factor for coral life at the study site are shown in Table 3.

Table 3 - Hydro Oceanographic Parameters

\begin{tabular}{llllll}
\hline Parameter & Station 1 & Station 2 & Station 3 & Station 4 & Station 5 \\
\hline Clarity $(\%)$ & 100 & 100 & 100 & 100 & 100 \\
Depth $(\mathrm{m})$ & 3,55 & 3,65 & 3,8 & 1,95 & 4,95 \\
Temp. $\left({ }^{\circ} \mathrm{C}\right)$ & 30,47 & 30,65 & 30,76 & 30,77 & 30,73 \\
Salinity $(\%$ ) & 35,78 & 35,92 & 36,2 & 35,74 & 31,6 \\
Current $(\mathrm{m} / \mathrm{s})$ & 0,27 & 0,17 & 0,12 & 0,075 & 0,33 \\
\hline
\end{tabular}

In general, the water quality at the time of research sampling on Samber Gelap Island was classified according to coral growth needs based on KepmenLH 51/2004. The measured clarity at all observation stations reaches $100 \%$ of the depth so that corals get enough light to carry out photosynthesis by zooxanthellae (Munasik, 2011; Khasanah et al., 2019). According to Sabdono et al. (2014) corals could still grow well at a surface light exposure limit of $30 \%$. The temperature in these waters was also included in normal conditions with a range of $30.5{ }^{\circ} \mathrm{C}$. According to Faturohman et al. (2016) and Duffy et al. (2016) that the measured temperature was within the optimal range that is $28-32^{\circ} \mathrm{C}$ so it supported the growth and reproduction of corals in these locations. Salinity in these waters had a value that exceeds the normal category with a range of 33-34 0/00 but was still within the tolerance range of the range 25-40 ${ }_{0}{ }^{00}$ so that it still supported coral life (Kultz, 2015; Hoey et al., 2016; Basu and Mackey, 2018). Besides that the current speed of the waters also influenced the coral life which in this study the highest current speed was found at station 5 of $0.33 \mathrm{~m} / \mathrm{s}$ and the lowest current speed was at station 4 of $0.075 \mathrm{~m} / \mathrm{s}$. Corals reef would have better 
growth in dynamic waters either stirred by wind, currents, or waves. This related to the function of currents in carrying nutrients and oxygen needed by corals, especially at night and also as a sediment rejector in cleaning coral reef surfaces from sediment deposits (Sahril, 2017; Saptarini et al., 2017).

Sampling of coral coverage was carried out at five stations with each station having three transects. The percentage of coral cover in the waters of Samber Gelap Island in general was $18.6 \%$ and included in the damaged category. The results of the percentage of coral coverage for each station are shown in Figure 2.

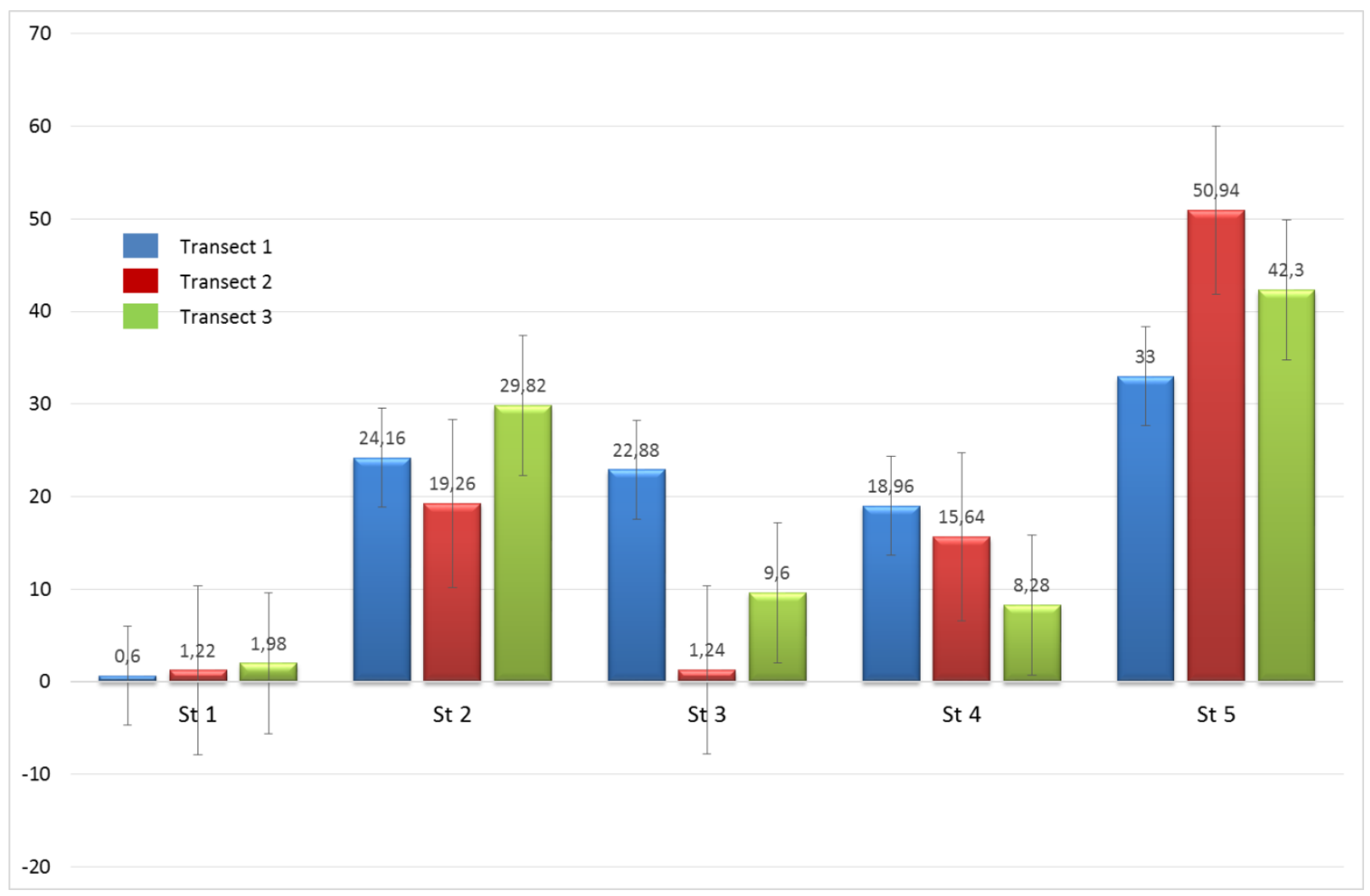

Figure 2 - Percentage of coral cover (\%)

The results of the calculation of coral cover data in the waters of Samber Gelap Island showed that the highest yield was found at station 5 with an average percentage of coral coverage of $42.08 \%$. These results were included in the medium category based on Kepmen LH number 4 of 2001 with cover values ranging from $25-50 \%$. This result was followed by station 2 with an average percentage of coral cover of $24.4 \%$, station 4 of $14.3 \%$, station 3 of $11.24 \%$, and station 1 of $1.26 \%$ all of which were included in the damaged category with a value of less than $25 \%$. The condition of corals classified as damaged on Samber Gelap Island was influenced by various things both naturally and anthropogenically that occured on land, coast or open sea (Baum et al., 2015; Hervey et al., 2018). These results as shown at station 1 with very low cover conditions had a sampling location around the landing area and fishing boat breaks. This condition caused a high level of stress on the coral ecosystem both caused by various human activities such as tourism that had not been well managed so that tourists could step on the coral reef causing damage to the coral ecosystem. Fishing boat anchors and tourists were also one cause of the damage (Fenner, 2012)

The results of this study indicated that there were four types of fish from the Chaetodontidae family with a total of 22 individuals. Chaetodontidae fish is a true coral reef fish that caused its distribution to be limited only around coral ecosystems. The existence and abundance of Chaetodontidae fish in waters could provide a description of the condition of coral reefs at these locations. This family of fish had a dependency on corals which were its food source, but not all types of fish consumed coral polyps as their main food (Coker et 
al., 2013). The abundance of Chaetodontidae fish in the Samber Gelap Island Waters can be seen in Figure 3.

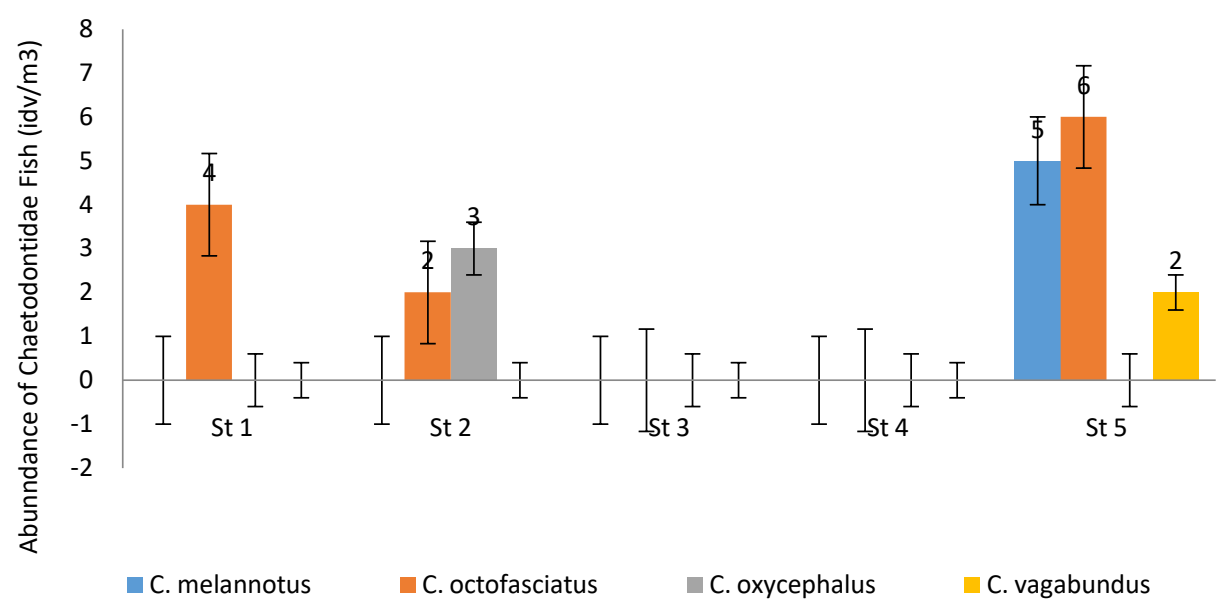

Figure 3 - Chaetodontidae Fish Abundance

There were four indicator fishes of the Chaetodon octofasciatus species which were included in the obligate coral feeder category at station 1 with the lowest percentage of coral coverage compared to other stations. Fish with this category made coral polyps the main food and indicated that the coral reefs at these locations were in good condition. However, if Chaetodon octofasciatus dominated, it could indicate that there had been a change in the coral reef ecosystem so that conditions were not good (Prato et al., 2017). Also according to Songploy et al. (2017), this type of fish was also commonly found living in areas that had a lot of rubble or dead coral. Chaetodon octofasciatus was often found in coral reef ecosystems that had been degraded due to the amount of pressure in the environment so that these fish might be used as indicators of coral reef degradation in an area (Maduppa et al., 2012).

To find out the relationship between the percentage of coral cover with the abundance of Chaetodontidae fish in the waters of Samber Gelap Island, a correlation test was performed as shown in Figure 4.

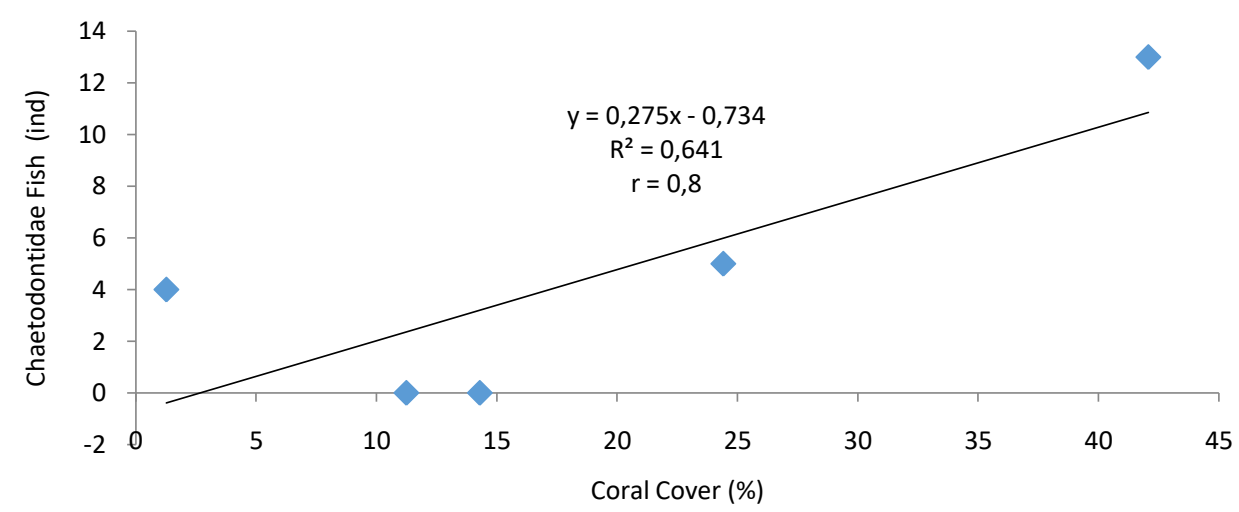

Figure 4 - Relationship of coral cover with abundance of indicator fish (Chatodontidae)

Based on data taken at each station, there was a positive relationship between the percentage of coral cover and the abundance of Chaetodontidae fish. The results of the 
correlation coefficient $(r)$ showed a value of 0.8 and means there was a very strong (significant) correlation between coral coverage and the abundance of Chaetodontidae fish (Nugraha et al., 2020). These results led to an interrelation between variables where if coral coverage had increased the abundance of Chaetodontidae fish in the Samber Gelap Island Waters would also increase. Messmer et al. (2011) said the increasing number of live coral reefs would have a direct impact on the food consumed by Chaetodontidae fish, especially the obligative coral reef feeder category, so as to increase the abundance of Chaetodontidae family fish in these waters.

\section{DISCUSSION of RESULTS}

Percentage of Coral Coverage. The high percentage of coral coverage at Station 5 was thought to be caused by the distance between the land and the observation site, thereby reducing the level of stress caused by various activities occurring on the coast and coast. Besides that, Station 5 also had a depth of up to 5 meters, thus minimizing damage caused by ship activities. Station 5 also had the highest current which functionedd in the circulation of water which carries oxygen and nutrient intake to the coral ecosystem and was also able to help the coral to remove sedimentary cover on its body surface. According to Sekerci and Petrovski (2015) that the presence of currents in coral ecosystems would accelerate the physiological recovery process so that coral conditions for the better. Besides being influenced by the environment, coral reefs which were the main habitat for underwater life also have an influence on the lives of other biota, including the abundance and diversity of fish Chaetodontidae (Putri et al., 2015).

Coral Indicator Fish (Chaetodontidae).In addition to station 1, indicator fish were also found in station 2 and station 5. In addition to having fish species of Chaetodon octofasciatus, this station also showed fish of the type of Chaetodon oxycephalus (station 2), Chaetodon vagabundus, and Chaetodon melannotus (station 5) which had functions different than Chaetodon octofasciatus. Chaetodon oxycephalus and Chaetodon melannatus, which were also obligated coral feeders, were bioindicators of coral reef ecosystems that had not been significantly disturbed so that coral reefs were still in relatively good condition (Coker et al., 2013). These results were in accordance with the calculation of the percentage of coral coverage which showed better results at station 2 and station 5 with medium and good categories. Whereas the Chaetodon vagabundus fish found at station 5 was a facultative coral reef feeder which not only ate coral polyps but also algae, invertebrates, or plankton so that it could not be used as a bioindicator of the condition of a coral reef in waters (Du et al., 2019). The low species of Chaetodontidae fish found in the waters of Samber Gelap Island was presumably due to ecological pressure on coral reefs due to activities on the coast and beach at these locations (Lehtonen et al., 2016).

Relationship Between Coral Reef Condition and Chaetodotontidae Fish. The high number of individual Chatodontidae fish in the Samber Gelap Island waters could reflect that the condition of a coral reef was in good condition, which was also identified by the high live coral coverage or in accordance with the function of its species (Komyakova et al., 2018). In addition, Figure 4 also showed the coefficient of determination (R2) with a value of 0.641 . This result meant that the influence of the independent variable (coral coverage) on the dependent variable (Chaetodontidae fish) was $64.1 \%$ while $35.9 \%$ was influenced by other variables. This result was supported by Nugraha et al. (2020) that the abundance of coral reef fish in an area was also influenced by various factors including coral rugosity (complexity), environmental conditions, and aquatic nutrition.

\section{ACKNOWLEDGEMENTS}

The author would like to thank LPDP as the BUDI-DN scholarship provider for the writer during the lecture until completing this dissertation research and Achmad Yani University Banjarmasin. 


\section{CONCLUSION}

Based on this study, it was concluded that the condition of the waters on Samber Gelap Island was included in both good and supportive categories of coral reef life. In general, the percentage of coral cover in this location was included in the damaged category with the highest coverage found at station 5 . The same results were also shown by the abundance of indicator fish from the Chaetodontidae family which had the highest number at station 5 compared to other stations. Correlation test showed a very strong relationship, but the results of this correlation also indicated that the abundance of coral reef fish in the waters of Samber Gelap Island, Kotabaru, South Kalimantan was not only influenced by the condition of coral cover, but was- also influenced by various other factors.

\section{REFERENCES}

1. Sabdono A., Radjasa O.K., Ambariyanto A., Trianto A., Wijayanti D.P., Pringgenies D., Munasik. International Journal of Zoological Research, 10, 2: 1-10 (2014).

2. Allen GR, Steene R. 1996. Indo-Pacific Coral Reef Field Guide. Tropical Reef Research.

3. Asmawi, S. dkk. 2010. Faktor Fisik Perairan and Antropogenik pada Terumbu Karang Kima si Perairan Bunati, Kabupaten Tanah Bumbu, Kalimantan Selatan.

4. Basu S, Mackey KRM. 2018. Phytoplankton as Key Mediators of the Biological Carbon Pump: Their Responses to a Changing Climate. Sustainability 10 (869): 1-18.

5. Baum G, Januar HI, Ferse SCA, Kunzmann A. 2015. Local and Regional Impacts of Pollution on Coral Reefs along the Thousand Islands North of the Megacity Jakarta, Indonesia. PLOS ONE 10(9): e0138271.

6. Burges, W E. 1978. Butterflyfishes of the World. Nepture City. T.F.H. Publication.

7. Coker DJ, Wilson SK, Pratchett MS. 2013. Importance of live coral habitat for reef fishes. Reviews in Fish Biology and Fisheries 24(1): 89-126.

8. Dahl AL. 1981. Coral Reef Monitoring Handbook. Sydney, Australia South Pacific Commission Publications Bureau.

9. Du J, Loh K, Hu w, Zheng X, Affendi YA, Ooi JLS, Ma Z, Rizman-Idid M, Chan AA. 2019. An updated checklist of the marine fish fauna of Redang Islands, Malaysia. Biodiversity Data Journal 7: e47537.

10. Duffy JE, Lefcheck JS, Stuart-Smith RD, Navarrete SA, Edgar GJ. 2016. Biodiversity enhances reef fish biomass and resistance to climate change. Proceedings of the National Academy of Sciences 113(22): 6230-6235.

11. Edrus IN, Wijaya SW, Setyawan IE. 2013. Struktur komunitas ikan karang di perairan Pulau Raya, Pulau Rusa, Pulau Rondo and Taman Laut Rinoi and Rubiah, NAD. Jurnal Penelitian Perikanan Indonesia. 19(4): 175-186.

12. English S, Wilkinson C, Baker V. 1994. Survei Manual for Tropical Marine Resources. Thailand: Department of Marine Science.

13. English, S. S., Wilkinson, C. C., \& Baker, V. V. (1997). Survey manual for tropical marine resources. Australian Institute of Marine Science. Townsville. Australia.

14. Faturohman I, Sunarto, Nurruhwati I. 2016. The Correlation of Plankton Abundance With Sea Water Temperature At Cirebon Steam Electricity Power Station. Jurnal Perikanan Kelautan VII (1): 115-122.

15. Fenner D. 2012. Challenges for Managing Fisheries on Diverse Coral Reefs. Diversity 4: 105-160.

16. Gomez, E. D., \& Yap, H. T. (1988). Monitoring reefcondition. Coral Reef Management Hand Book. Unesco Regional office for South East Asia. Jakarta. pp. 171-178.

17. Harvey BJ, Nash KL, Blanchard JL, Edwards DP. 2018. Ecosystem-based management of coral reefs under climate change. Ecology and Evolution 8(12): 6354-6368.

18. Hoey AS, Howells E, Johansen JL, Hobbs JA. 2016. Recent Advances in Understanding the Effects of Climate Change on Coral Reefs. Diversity 8(12): 1-22.

19. Iskandar R, Tony F. 2013. Sedimentation Study at Angsana River in Angsana District, Tanah Bumbu Regency, South Kalimantan. Enviro Scienteae 9:106-111. 
20. KepMenLH. (2001). "Kriteria Baku Kerusakan Terumbu Karang." 4Retrieved 29 Maret 2016, from: http://bppi.kemenperin.go.id/extension/panduaniso/doc/uu/J07-200100004.pdf.

21. Khasanah, RI, Herawati EY, Hariati AM, Mahmudi M, Sartimbul A, Wiadnya DGR, Asrial E, Yudatomo, Nabil E. 2019. Growth rate of Acropora formosa coralfragments transplanted on different composition of faba kerbstone artificial reef. Biodiversitas 20(12): 3593-3598.

22. Komyakova V, Jones GP, Munday PL. 2018. Strong effects of coral species on the diversity and structure of reef fish communities: A multi-scale analysis. PLoS ONE 13(8).

23. Kültz D . 2015. Physiological mechanisms used by fish to cope with salinity stress. Journal of Experimental Biology 218(12): 1907-1914.

24. Lehtonen TK, Wong BBM, Kvarnemo C. 2016. Effects of salinity on nest-building behaviour in a marine fish. BMC Ecology 16(1): 1-9.

25. Madduppa HH, Agus SB, Farhan AR, Suhendra D, Subhan B. 2012. Fish biodiversity in coral reefs and lagoon at the Maratua Island,East Kalimantan. Biodiversitas 13(3):145150.

26. Messmer V, Jones GP, Munday PL, Holbrook SJ, Schmitt RJ, Brooks AJ. 2011. Habitat biodiversity as a determinant of fish community structure on coral reefs. Ecology 92(12): 2285-2298.

27. Munasik, 2011, Hard Coral Community (Scleractinia) Community Structure in Marabatuan and Matasirih Islands, South Kalimantan. Indonesian Journal of Mariene Sciences 16(1) 14-21.

28. Nachtsheim, C. J., Neter, J., Li, W., \& Kutner, M. H. (2004). Applied linear statistical models. Journal of the Royal Statistical Society Series A General, Fifth, 1396.

29. Nugraha, W. A. dkk. 2020. The Correlation of Coral Reef Cover and Rugosity with Coral Reef Fish Density in East Java Waters. JIPK. Vol. 12. No. 1.

30. Odum, E. P. 1994. Dasar-dasar Ekologi. Catatan ke-3. Gajah Mada University Press. Yogyakarta.

31. Prato G, Thiriet P, Di Franco A, Francour P. 2017. Enhancing fish Underwater Visual Census to move forward assessment of fish assemblages: An application in three Mediterranean Marine Protected Areas. PLOS ONE 12(6): e0178511.

32. Putri MR, Setiawan A, Safitri M. 2015. Variation of ocean $\mathrm{pH}$ in the Indonesia waters. In: The 5th International Conference on Mathematics and Natural Sciences AIP Conference Proceedings. Bandung Institute of Technology, Bandung, 2-3 November 2014.

33. Rondonuwu AB, Rembet UNWJ. 2013. Ikan Karang Famili Chaetodontidae di Terumbu Karang Pulau Para Kecamatan Tatoareng Kabupaten Kepulauan Sangihe. Jurnal IImiah Platax. 1(4).

34. Sahril A, 2017. Analysis of Dissolved Oxygen Parameters in Southern Ocean Island Waters as an Indicator of Pollution in Kotabaru District. [Research Report] Lambung Mangkurat University, Banjarbaru. [Indonesian].

35. Saptarini D, Mukhtasor, Rumengan IFM. 2017. Coral reef lifeform variation around power plant activity: Case study on coastal area of Paiton Power Plant, East Java, Indonesia. Biodiversitas 18(1): 116-120.

36. Sekerci Y, Petrovskii S. 2015. Mathematical Modelling of Plankton-Oxygen Dynamics Under the Climate Change. Bulletin of Mathematical Biology 77(12): 2325-2353.

37. Setiawan F. 2010. Panduan Lapangan Identifikasi Ikan Karang and Invertebrata Laut. Bogor: Ilmu and Teknologi Kelautan Institut Pertanian Bogor.

38. Songploy S, Chavanich S, Kuanui P, Viyakarn V. 2017. Diversity of reef fish at Royal Thai Naval Base, Sattahip, Chonburi Province, Thailand. Indian Journalof Geo Marine Sciences 46(6):1220-1225.

39. Suharsono. 2008. Jenis-Jenis Karang di Indonesia. Jakarta: Pusat Penelitian Oseanografi -LIPI.

40. Suharyanto, Utojo. 2007. Kondisi Ikan Karang di Teluk Pare-Pare and Awerange Sulawesi Selatan. Biodiversitas. 8(2): 101-104.

41. Veron J. 2000. Corals of the World. Australia: Australian Institute of Marine Science. 